\title{
Dark and Bright Side of Claiming Discrimination: Making Attributions to Prejudice and Social Wellbeing among Immigrants in Spain *
}

\section{Dos Lados de Reclamar la Discriminación: Atribuciones al Prejuicio y Bienestar Social en las Personas Inmigrantes en España}

\author{
Magdalena BoBOWiK ${ }^{\mathrm{a}}$ \\ University of the Basque Country, España \\ ORCID: http://orcid.org/0000-0002-2341-0665 \\ ANNA WLODARCZYK \\ Universidad Católica del Norte, Chile \\ Siu Lay-Lisboa \\ Universidad Católica del Norte, Chile
}

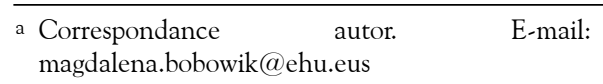

How to cite: Bobowik, M., Wlodarczyk, A., \& LayLisboa, S. (2017). Dark and Bright Side of Claiming Discrimination: Making Attributions to Prejudice and Social Wellbeing among Immigrants in Spain. Universitas Psychologica, 16(5), 1-15. https:// doi.org/1 0.11144/Javeriana.upsy16-5.dbsc

\begin{abstract}
Research on the consequences of making attributions to prejudice for the psychological functioning of minority groups is still scarce and rather inconsistent. In this study we set out to examine the consequences of making attributions to prejudice in response to social rejection for social wellbeing among immigrants in Spain. We tested this relationship and the mediating effects with representative samples of 1250 foreignborn immigrants who had lived for at least six months in the Basque Country, having been born in Bolivia, Colombia, Morocco, Romania, or Sub-Saharan African countries. The sample was drawn from public records and obtained through a probability sampling procedure by ethnicity with stratification by age and sex. We conducted mediation analyses using structural equation modeling (SEM) to verify whether the perceived ethnic discrimination effect on the five dimensions of social wellbeing was partially or completely explained by the attributions to prejudice. Our results indeed partially revealed that making attributions to prejudice protect social wellbeing form negative consequences of personal discrimination only in the dimension of social contribution. In turn, attributions to prejudice explained the negative relationship between perceived discrimination, and social acceptance and social actualization: that is, those dimensions of social wellbeing that reflect social trust. We discuss the results integrating social identity, social stigma, and positive psychology framework, through the inclusion of societal aspects of wellbeing for measuring immigrants' adaptation in the host society.
\end{abstract}

Keywords

immigration; perceived discrimination; attributions to prejudice; wellbeing.

\section{RESUMEN}

La investigación sobre las consecuencias de hacer atribuciones al prejuicio en el funcionamiento psicológico de los grupos minoritarios 
sigue siendo escasa y bastante inconsistente. En este estudio nos propusimos examinar las consecuencias de hacer atribuciones al prejuicio en respuesta al rechazo social para el bienestar social de las personas inmigrantes en España. Comprobamos nuestras predicciones en una muestra representativa de 1250 personas inmigrantes nacidas en el extranjero que habían vivido por lo menos seis meses en el País Vasco, habiendo nacido en Bolivia, Colombia, Marruecos, Rumania o países del África subsahariana. La muestra se extrajo de registros públicos y se obtuvo mediante un procedimiento de muestreo probabilístico por etnia con estratificación por edad y sexo. Se realizaron análisis de mediación, utilizando el modelo de ecuaciones estructurales (SEM) para verificar si el efecto percibido de discriminación étnica sobre las cinco dimensiones del bienestar social fue parcial o completamente explicado por las atribuciones al prejuicio. Nuestros resultados revelaron que las atribuciones al prejuicio en parte protegen el bienestar social, teniendo consecuencias negativas la discriminación personal sólo la dimensión de la contribución social. A su vez, las atribuciones al prejuicio explicaron la relación negativa entre discriminación percibida y aceptación social y actualización social: es decir, estas dimensiones del bienestar social que reflejan la confianza social. Discutimos los resultados en el marco de las teorías de la identidad social, el estigma social y de la psicología positiva, a través de la inclusión de los aspectos sociales del bienestar para medir la adaptación de los inmigrantes en la sociedad de acogida.

Palabras clave

inmigración; discriminación percibida; atribuciones al prejuicio; bienestar.

\section{Introduction}

In face of the intensive growth of minority populations, in the European Union, as well as in other regions or countries, in recent decades attitudes toward immigration have become more restrictive (Meuleman, Davidov, \& Billiet, 2009). Thus, being a member of ethnic minority frequently involves being marked with a social stigma and experiencing discrimination. European surveys indeed confirmed that immigrant and ethnic minorities feel stigmatized, particularly Sub-Saharans (41\%) and North Africans (36\%) (see European Union Agency for Fundamental Rights, 2010), which are also those minority groups who feel more discriminated against compared to Latino immigrants in Spain (Basabe \& Bobowik, 2013). A question of considerable interest is how perceptions of discrimination relate to immigrants' wellbeing and what are the mechanisms explaining this link. A great deal of research on immigrants' and ethnic minorities' wellbeing has corroborated that perceived ethnic or racial discrimination has negative outcomes (Finch, Kolody, \& Vega, 2000; González-Castro \& Ubillos, 2011; Williams, Neighbors, \& Jackson, 2003; Williams \& Mohammed, 2009; Branscombe, Schmitt, \& Harvey, 1999; Mesch, Turjeman, \& Fishman, 2008; Schmitt, Branscombe, Postmes, \& Garcia, 2014; Pascoe \& Smart-Richman, 2009). Research with immigrants in Spain has also revealed that perceived discrimination was one of the strongest predictors of immigrants' physical and mental health (Sevillano, Basabe, Bobowik, $\&$ Aierdi, 2014), and was also negatively related to wellbeing (Bobowik, Martinovic, Basabe, Barsties, \& Wachter, 2017).

However, stigmatized individuals are not passive victims of prejudice and discrimination, but rather act to deal with their negative social identity or social stigma in order to preserve their wellbeing (Crocker, Major, \& Steele, 1998; Miller \& Kaiser, 2001; Major \& O'Brien, 2005; Tajfel \& Truner, 1979). That is, minority group members can "take matters into their own hands" and act in a variety of ways to deal with the situation. One of the responses to discrimination may be attributing the devalued status and identity to prejudice and discrimination (Crocker et al., 1998). Yet, research addressing the question how making attributions to prejudice translates into wellbeing is still scarce and mostly limited to examining the link between these attributions and classic indicators of adjustment such as self-esteem. In this, we set out to examine the consequences of making attributions to prejudice in response to social rejection for social wellbeing among members of groups with disadvantaged status. Adopting the perspective of positive psychology, we place special emphasis on a variety of possible displays and nuances of wellbeing in immigrants, with a special focus on social wellbeing. 


\section{Immigration and Social Wellbeing}

Looked at through the lens of the Ulysses syndrome, immigrants are perceived as exhausted, frightened, depressed, hopeless, and always yearning for what they have lost. There is no doubt that migration implies stress and that acculturation is effortful, but it need not involve a feeling of loss or be a predominantly negative, grievous experience. This perspective frequently overlooks the fact that people choose to migrate in search of opportunities for achieving personal, social, and economic benefits, to gain personal autonomy and control, to develop new friendships and social networks, or to grow personally. Positive psychology provides tools for describing these positive aspects of the encounter between cultures, even in adverse circumstances, shifting the focal point from illbeing to wellbeing.

Wellbeing, combining different aspects of the human condition, can be defined as an optimal psychological functioning and experience, which favors not only a positive hedonic state (i.e., the prevalence of positive emotions over negative ones and to the level of satisfaction with life and its specific domains) but also the development of skills and personal growth, frequently referred to as eudaimonic wellbeing (Ryan \& Deci, 2001). Together with psychological wellbeing, an important aspect of eudaimonic wellbeing is social wellbeing, which covers five domains: social integration (a feeling of belongingness and being accepted), social acceptance (an accepting view of human nature and trust in others), social contribution (a belief in having something to contribute to society), social actualization (a belief in the potential and growth of the society and therefore a feeling of hope about its future), and social coherence (knowledge about and an understanding of social life) (Keyes, 1998; 2006). Social wellbeing can be considered a "public" facet of eudaimonic wellbeing because it focuses on the appraisal of one's functioning in the society and provides an explanation for how society affords us wellbeing (Keyes, 1998; Keyes, 2006). It is therefore a particularly relevant, societal aspect of wellbeing, worth of study in such populations as immigrants.

Yet, research has still scarcely addressed ethnic minorities' or immigrants wellbeing in terms of psychological or social wellbeing (but see AbuRayya \& Abu-Rayya, 2009; Bobowik et al., 2014; Bobowik, Basabe, \& Páez, 2015; Iwamoto \& Liu, 2010; Joshanloo, Bobowik, \& Basabe, 2016; Ryff, Keyes, \& Hughes, 2003; Keyes, 2009). Empirical evidence suggests that Blacks show a great advantage over Whites in social coherence, actualization, and integration, after adjustment for perceived discrimination (Keyes, 2009). Blacks also showed a more subtle advantage over the majority group in terms of social contribution, though not in terms of social acceptance. These results suggest that indeed immigrants' wellbeing is a multi-dimension construct and that while the experience of immigration may be costly for some aspects of wellbeing, it may be beneficial for its other facets. Still, particularly few studies have focused on social wellbeing among migrants (Keyes, 2006), while these aspects of the individual's functioning are crucial ones in the examination of immigrant populations because they refer to those social tasks that could be particularly challenging for an immigrant person in a new community. Thus, in this study we aimed to explore the relationship between perceived discrimination, making attributions to prejudice, and social wellbeing in a representative sample of foreign-born immigrants.

\section{The Consequences of Making Attributions to Prejudice}

Social stigma scholars propose a model in which an attribute that is given a negative social identity, and hence results in the stigmatization of certain social groups, can be confronted by means of individual coping resources in order to preserve one's self-esteem (Crocker et al., 1998). The group that is the object of devaluation can be defended against the stigmatizing outgroup by means of the strength of the collective identity, used as a social resource for coping with discrimination. According to 
social stigma framework, individuals may opt for a variety of responses to protect their positive selfconcept. The three classic strategies in the social stigma model are more passive responses, such as psychological disengagement, and responses requiring stronger identity involvement in the processes related to stigmatization, such as making attributions for negative outcomes to prejudice or diverse types of social comparison. Research has confirmed that in situations when there are no possibilities for individual mobility or disengaging from group membership, minority members would turn to collectivistic strategies (Bobowik, Basabe, Páez, \& Rosel, 2017; Mummendey, Kessler, Klink, \& Mielke, 1999), including attributing the devalued status and identity to prejudice and discrimination (Crocker \& Major, 1989; Crocker et al., 1998; Crocker, Voelkl, Testa, \& Major, 1991; Swim \& Stangor, 1998). Namely, stigmatized people who attribute poor outcomes to prejudice instead of placing the responsibility on themselves blame the unfairness of other people, and making such attributions can protect their self-esteem (Crocker et al., 1998).

The assumption regarding the "healing" nature of making attributions to prejudice has its roots in classical literature on attributional style and its consequences for mental health or wellbeing (e.g., Abramson et al., 1978; Seligman et al., 1979). People can attribute life events to situational (external, e.g., discrimination) or personal (internal, e.g., lack of abilities) causes (Heider, 1958; Kelley, 1967), as well as pervasiveness or variability over time of the cause (Weiner, 1972). Thus, individuals who tend to attribute negative outcomes to internal (versus external), stable (versus temporal), and global (versus specific) factors, are higher on risk for development of helplessness and thus depression (e.g., Abramson et al., 1978; Zautra et al., 1985). In another study, Cheng and Furrnham (2003) found that internality and globality of attributional style where negatively related with self-esteem but not with positive and negative affect, and only a composite pessimistic attributional style predicted overall happiness.
In turn, attributing these negative events to external causes may serve as a protective mechanism against depression or favour positive self-esteem. Blaming prejudice for one's or one group's negative outcomes could be then considered an external cause and thus serve as an adaptive coping mechanism that buffers negative effects of discrimination on self-esteem or wellbeing, in line with social stigma framework (Crocker \& Major, 1989; Crocker et al., 1998). Indeed, some studies have shown that attributions to discrimination help to maintain positive self-esteem and lower levels of depressive symptoms (Crocker \& Major, 1989; Crocker et al., 1991). However, Schmitt and Branscombe (2002) argue that people can see their group as a cause of discrimination without assigning blame to the self or group membership and such blame assignment may not necessarily have similar outcomes as causal locus of attributions because attributions to prejudice can have internal (group membership) and external (prejudiced society) locus simultaneously. Further, these authors argue that for most disadvantaged groups discrimination is a pervasive and incontrollable experience (Schmitt \& Branscombe, 2002) that has negative consequences for wellbeing (Branscombe et al., 1999).

Indeed, these strategies may also entail a social cost for members of the ingroup (Kaiser \& Miller, 2001; Kaiser, Dyrenforth, \& Hagiwara, 2006; Stroebe, Dovidio, Barreto, Ellemers, \& Sue John, 2011). That is, individuals who attribute their negative outcomes to discrimination are perceived less favorably (Kaiser \& Miller, 2001). Research has also demonstrated when discrimination was presented as pervasive (versus rare), attributions to prejudice were found to be harmful and only when discrimination was perceived as rare they led to higher selfesteem and lower depressive symptoms (Stroebe et al., 2011). In another study, attributions to discrimination were unrelated with selfesteem directly but indirectly undermined selfesteem through appraisal of the severity of discrimination (Eccleston \& Major, 2006). Prejudice ambiguity may also be another mechanism explaining why attributions to 
prejudice may be costly (Major, Quinton, \& Schmader, 2003). This kind of response, although based on cognitive re-evaluation, is also emotion-loaded. Attributing negative outcomes to prejudice and discrimination -as well as social comparisons made on the basis of such attributions- would usually lead to feelings of discontent, injustice and frustration, and may be negatively related to wellbeing (Skinner, Edge, Altman, \& Sherwood, 2003), but can also reinforce social mobilization (Guimond \& Tougas, 1996).

\section{Current Research}

The contribution of the present study is manifold. First, due to still scarce research on the consequences of making attributions to prejudice for the psychological functioning of minority groups as well as the inconsistent findings of the existing research, further testing this link is necessary. Also, research testing the mediating role of making attributions to prejudice in the relationship between perceived discrimination and wellbeing is scarce. Second, we tested this relationship and the mediating effects with representative samples of foreign-born voluntary immigrants in Spain. To our knowledge, existing research was mostly conducted with convenience samples and with regard to gender (Major et al., 2003; Schmitt \& Branscombe, 2002; Stroebe et al., 2011) or racial discrimination (Major et al., 2003), or explored in general the link between attributional style and wellbeing (Cheng \& Furnham, 2003). Third, we covered a still understudied facet of psychological functioning, i.e. eudaimonic components of wellbeing as an outcome, which up to now have scarcely been studied among minority groups (e.g., Iwamoto \& Liu, 2010; Ryff et al., 2003; Keyes, 2009). More precisely, we explored nuances in the relationship between making attributions to prejudice and five different facets of social wellbeing.

Finally, it is important to consider the specific context of this study. Spain is a European country that after some decades of economic growth has experienced an abrupt inflow of migrant populations. These new sociodemographic trends have transformed Spain into a country with one of the highest net migration rates in Europe (Eurostat, 2012; International Organization for Migration, 2010), and therefore one whose society is becoming multi-ethnic. As a consequence of these changes, today immigrants account for around $10 \%$ of the population in Spain as a whole and $8.9 \%$ in the Basque Country (Basque Observatory of Immigration, 2017), the region on which this paper focuses. Particularly now, given the hardships brought on by Spain's economic crisis, immigrants' positive self-concept has become more vulnerable in view of the increasingly negative attitudes toward them (Meuleman et al., 2009). Immigrants' wellbeing and its determinants, together with the relevant underlying processes and consequences, should therefore be of particular interest for both social and positive psychology scholars.

\section{Method}

\section{Participants}

The sample consisted of 1250 foreign-born immigrants who had lived for at least six months in the Basque Country, having been born in Bolivia, Colombia, Morocco, Romania, or Sub-Saharan African countries. There were 250 participants in each of the cultural groups. Within the sample, $44.3 \%$ of the participants were female and mean age was 33.22 years $(S D=9.44)$, ranging from 18 to 64. Average time of residence of the participants was 6.26 years $(S D=4.83)$. Thirteen percent of the respondents had no formal education, $30.7 \%$ had completed primary education, $41.9 \%$ secondary education, and 14.2\% university. Most participants described themselves as Catholic (43\%), the rest being Muslim (29.2\%), or professed other religion (20.4\%). Only a minority were Protestant (1.8\%) or non-believers $(3.7 \% ; 2.3 \%$ did not respond). More than half lived with their partner $(63 \%)$. Whilst $47.6 \%$ were professionally active, $42.1 \%$ were unemployed or looking for a job (there 
rest were housewives, students, or retired). The majority of the participants had their legal status regularized: $49.9 \%$ had a residence permit, 20.6\% (predominantly Romanians) had European Union citizenship, and $4.4 \%$ were naturalized. However, $23.1 \%$ of the total sample were living in Spain without a residence permit. Net household income in the case of $45.5 \%$ of the respondents ranged from 600 to 1800 euros, whilst for $30.2 \%$ it was below 600 euros. Only for $5.5 \%$ of the participants did their household income exceed 1800 euros (18.8\% of the respondents failed to provide information on their household income). As for the sociodemographic characteristics of the sample, there was no missing data, or it never exceeded $4 \%$.

\section{Procedure}

This cross-sectional study is based on questionnaire data collected between December 2009 and February 2010 in the Basque Country, an autonomous region in northern Spain. The study guaranteed the confidentiality of the survey participants' responses, and all procedures were approved by the University of the Basque Country's Ethics Committee for Research Involving Human Beings. All study participants signed written informed consent. The research team was responsible for alphanumerically coding the registered data, ensuring anonymity.

The sample was drawn from public records and obtained through a probability sampling procedure by ethnicity with stratification by age and sex (CI 95\%, sigma 1.96; Error 92.77). The participants were recruited by random routes in their households, whereby one route was randomly selected in a random section of each of the census districts. Only one interview was carried out per household. Given the difficulties for the sampling of special populations (known as rare events), once a particular random route stopped giving a marginal gain in the probability of success by moving away from the areas with the highest density of the study population, the route was rearranged by assigning a new starting point in the district. Only exceptionally were quotas completed by a snowball sampling technique, and always respecting pre-established quotas.

The sample was drawn from public records and the data were collected by a team of trained interviewers. Respondents participated in a fully structured, face-to-face interview. Participants were asked to answer a series of closed questions and informed that their participation was voluntary and their responses confidential. The interviewers were provided with detailed fieldwork instructions and a set of show-cards displaying the corresponding fixed categories to be used when asking each question. Interviews were conducted in Spanish, as for the Latino immigrant groups this is their native language and the vast majority of the other immigrant groups in Spain are able to speak and understand it. However, many of the interviewers were bilingual and all were provided with English and French versions of the questionnaire as backup.

\section{Measures}

Perceived ethnic discrimination. The scale consisted of five items on a 5-point Likert scale ranging from (1) never to (5) almost always assessing the frequency of being personally treated negatively due to one's ethnic background or immigrant status (see Bobowik et al., 2017; Sevillano et al., 2014). Respondents were asked, 'how frequently have people from here, either Basque or Spanish: "made you notice that: you are an economic threat to them (taking away jobs, taking advantage of medical care benefits)?," "made you feel discriminated against (noticing looks, hearing negative expressions or attitudes) due to your physical appearance?," "been aggressive, insulting, or threatening with you?," "given you hostile treatment that they would never give to other Basque or Spanish people?," and "made you feel ignored, neglected or ostracized?"'. This measure of perceived ethnic discrimination was reliable across the five groups $(\alpha=0.88)$. This measure is similar to other measures of discrimination applied in literature (Williams \& Mohammed 2009), and was used 
in previous studies with immigrant populations in the Basque Country (Zlobina, Basabem, Páez, \& Furnham., 2006, N = 642; Aierdi, Basabe, Blanco, \& Oleaga, 2008; Basabe, Páez, Aierdi, \& Jiménez-Aristizabal, 2009, $\mathrm{N}=3000$ ), showing satisfactory reliability coefficients (from 0.87 to 0.88).

Attributions to prejudice. The items for measuring attributions to prejudice were developed for the purpose of a larger survey using the existing literature and based on Blanz, Mummendey, Mielke, and Klink (1998) taxonomy of identity management strategies (see Bobowik et al., 2014). All the items were positively worded, and responses were on a fivepoint response scale $(1=$ strongly disagree to $5=$ strongly agree). The items composing this scale were "The bad situation of immigrants from my country is caused by a lack of support from the Basques and the Spaniards", "The poor view that some Basques hold of immigrants is because these people have a lot of prejudices", and "Immigrants earn less money and have fewer opportunities to better themselves than they deserve". An exploratory factor analysis of principal components with Varimax rotation showed only one factor, which explained $51.78 \%$ of the variance. The Cronbach's alpha reliability coefficient was 0.53 .

Social wellbeing. A total of 14 items adapted for this study (see Bobowik, Basabe, \& Páez, 2014; 2015; Joshanloo et al., 2016; adapted from the 15-item scale developed by Keyes, 1998; 2009) were used to assess five dimensions of participants' social wellbeing. Participants were asked to think about people in the community they feel part of, and to indicate on a scale ranging from 1 (completely disagree) to 5 (fully agree) to what extent they agreed with a series of sentences referring to that community. Following the findings from previous research (Bobowik, Basabe, \& Páez, 2014; 2015; Joshanloo et al., 2016) we assessed the five dimensions of social wellbeing: social contribution (e.g., "I have something important to contribute to the society," $\alpha=0.73$ ), social integration (e.g., "I feel I belong to something I'd call a community," $\alpha$ $=0.71$ ), social actualization (e.g., "Our society is becoming a better place for people like me," $\alpha=0.83$ ), social acceptance (e.g., "People are basically good," $\alpha=0.63$ ), and social coherence (e.g., "I cannot make sense of what's going on in the world," $\alpha=0.7$, for two items).

\section{Analyses}

Considering the aims of the present study, we focused on whether the perceived ethnic discrimination effect on the five dimensions of social wellbeing was partially or completely explained by the attributions to prejudice. We conducted mediation analyses using structural equation modeling (SEM). Unlike regressionbased approaches to mediation, the SEM approach to mediation uses model-fit criteria to determine whether the proposed mediation model provides a plausible fit to the data. Similar to regression-based approaches, we also examined the significance of the indirect effect of the perceived ethnic discrimination on the five dimensions of social wellbeing. The models were tested using Mplus 7 (Muthén \& Muthén, 2010). The estimation procedure applied was maximum likelihood (ML). For the assessment of model fit, both chi-square statistics and goodness-offit criteria were used, namely: a) the chi-square statistic, expected to take low values and be nonsignificant; b) the Comparative Fit Index (CFI) and Tucker-Lewis Index (TLI), as indicators of goodness-of-fit, with values of over 0.9 being considered acceptable (Hu \& Bentler, 1999; Tucker \& Lewis, 1973); and c) the Root MeanSquare Error of Approximation (RMSEA), with its confidence interval $(\mathrm{CI})$ and a cut-off value close to 0.06 , indicating a relatively good fit $(\mathrm{Hu}$ $\&$ Bentler, 1999).

To test the mediation hypotheses, we computed indirect effects (standardized estimates are presented) and tested their significance based on bootstrapped (unstandardized) confidence intervals. The bootstrap method is a non-parametric approach to parameter estimation, and hence free from assumptions about the normality of the variables' distributions or the sampling 
distribution of the statistic (see Efron \& Tibshirani, 1993). This method consists in the repeated extraction of samples from the dataset and the estimation of the desired statistic in each of the resampled datasets. Standard errors and confidence intervals based on a bootstrap sampling distribution are calculated for each of the parameters or statistics. If the values of the estimated effect within the confidence interval include zero, this indicates a nonsignificant effect. In the presentation of the results, the standardized solution is shown. All the coefficients represented by continuous arrows in the graphs are statistically significant, while the dashed lines indicate effects that are not statistically significant for $p<0.05$.

\section{Results}

\section{Descriptive Data and Correlations}

Means and standard deviations for the perceived ethnic discrimination, the attributions to prejudice, and the five dimensions of social wellbeing are presented in Table 1. Additionally, Table 1 also shows intercorrelations among the model components.

\section{TABLE 1}

Means, Standard Deviations, and correlations between the study variables

\begin{tabular}{llllllll}
\hline & M (SD) & DISCR & ATR & INT & CON & ACT & (ii) COH \\
\hline DISCR & $1.66(0.86)$ & 1 & & & & & \\
ATR & $3.46(0.88)$ & $0.198^{* *}$ & & & & & \\
INT & $3.81(0.79)$ & $-0.282^{* *}$ & -0.039 & & & & \\
CON & $3.92(0.73)$ & $-0.194^{* * *}$ & 0.034 & $0.436^{* *}$ & & & \\
ACT & $2.99(1.15)$ & $-0.332^{* *}$ & $-0.167^{* *}$ & $0.327^{* *}$ & $0.245^{* *}$ & & \\
(in)COH & $3.040(0.85)$ & $0.242^{* *}$ & 0.017 & $-0.2^{* *}$ & $-0.181^{* *}$ & $-0.241^{* *}$ & \\
ACP & $1.66(0.86)$ & $-0.291^{* *}$ & $-0.134^{* *}$ & $0.392^{* *}$ & $0.25^{* *}$ & $0.585^{* *}$ & $-0.17^{* *}$ \\
\hline
\end{tabular}

Note. DISCR = Perceived Ethnic Discrimination; ATR $=$ making attributions to prejudice; INT = social integration; $\mathrm{CON}=$ social contribution; ACT $=$ social actualization; $($ in $) \mathrm{COH}=($ low $)$ social coherence; $\mathrm{ACP}=$ social acceptance. $* * p>0.01$ (1-tailed). Source: own work.

We found that perceived ethnic discrimination was negatively associated with all the five dimensions of social wellbeing. In case of the attributions to prejudice, correlations were negative and significant only for the dimensions of social actualization and social acceptance. All the five dimensions of social wellbeing were positively intercorrelated ranging from $r=0.17$ (social coherence and social acceptance) to $r=$ 0.58 (social acceptance and social actualization). Finally, it is worth mentioning that although the ethnic discrimination may be perceived as relatively low, the mean score of attribution to prejudice is rather high. As to the dimensions of social wellbeing, the mean scores of social contribution and social integration were found to be the highest, following by low social coherence and social actualization; whereas social acceptance the least reported. This result indicates that it is crucial to analyses the facets of social wellbeing separately as they may not all be equally common and may be influenced by different mechanism or perceptions.

Structural Equation Modeling: Mediation effects of Making Attributions to Prejudice in the Relationship between Perceived Ethnic Discrimination and Social Wellbeing

Therefore, in the next step, we tested a mediational model in which perceived ethnic discrimination was proposed to predict directly and indirectly, through making attributions to prejudice, all the five dimensions of social wellbeing. In this model all the latent variables were specified as correlated exogenous constructs. Each item was allowed to load only on its designated latent factor and no errors were allowed to correlate. The complete model obtained a good fit $\left[\chi^{2}(1250,188)=861.978, p\right.$ $<0.001, \mathrm{CFI}=0.931$, TLI $=0.915$, RMSEA $=$ 0.054 (90\% CI $[0.05,0.057])]$. All items loaded rather highly on their designated latent factor (all factor loadings $>0.425$; average factor loading around 0.69) and were significant based on $95 \%$ bootstrapping confidence intervals. 


\section{Figure 1}

Mediational model: perceived ethnic discrimination, attributions, and dimensions of social wellbeing

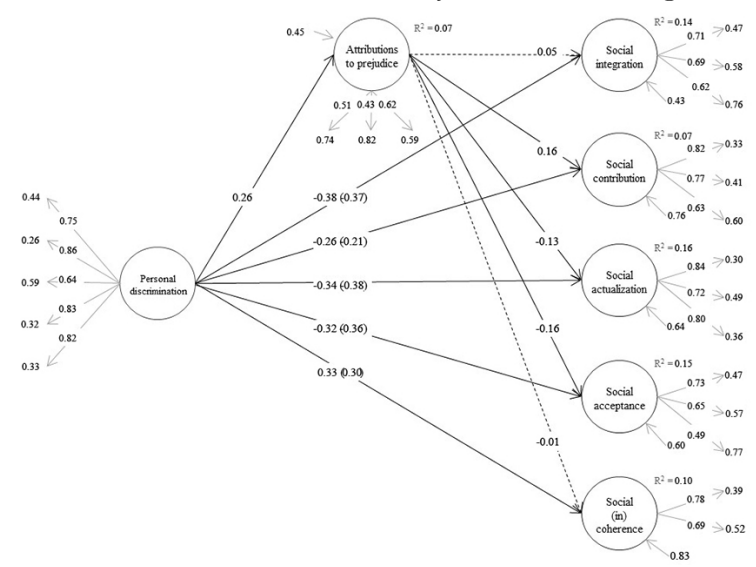

Note. Standardized direct coefficients are shown. Values in parentheses represent total effects. Source: own work.

As can be seen in Figure 1, perceived ethnic discrimination acted as a direct predictor of all the dimensions of social wellbeing and at the same time enhanced attributions to prejudice. Moreover, the attribution to prejudice was positively related to social contribution and negatively to both social actualization and social acceptance, whereas the effect on social integration and social (in) coherence did not reach conventional levels of statistical significance. Furthermore, the relationship between ethnic discrimination and the dimensions of social wellbeing was observed to be partially mediated by the attributions to prejudice. Perceived ethnic discrimination showed a significant indirect effect through attributions to prejudice on social contribution $(\mathrm{B}=0.04, \mathrm{SE}=0.01$, Est./S.E $=3.2, p=0.001$, $99 \%$ CI $[0.008,0.078])$; on social acceptance (B $=-0.04, \mathrm{SE}=0.01$, Est./S.E $=-3.02, p=0.003$, 99\% CI [-0.076, -0.006]); on social actualization $(\mathrm{B}=-0.04, \mathrm{SE}=0.01$, Est. $/ \mathrm{S} . \mathrm{E}=-2.83, p$ $=0.003,99 \%$ CI $[-0.067,0.003])$ but not on social integration or social coherence. That is, perceived discrimination led to higher attribution to prejudice which in turn was related to higher social contribution and lower social acceptance and social actualization.
In sum, discrimination was related to lower social acceptance and lower social actualization because it increases making attributions to prejudice. In turn, making attributions to prejudice protects the feeling of social contributions from detrimental effects of discrimination.

\section{Discussion}

Making attributions to prejudice is a collective strategy, which means placing responsibility for the negative outcomes on the unfairness of other people. The social stigma paradigm suggests that making an attribution to prejudice can protect self-esteem (Crocker \& Major, 1989; Crocker et al., 1998; 1991), but other studies have shown that it can also involve a social cost for the stigmatized individuals (Kaiser \& Miller, 2001; Kaiser et al., 2006; Stroebe et al., 2011). Our results indeed partially confirm and extend the latter assertion: Making attributions to prejudice did protect social wellbeing form negative consequences of personal discrimination but only on the dimension of social contribution. Nevertheless, it rather had a negative effect on other dimensions of social wellbeing.

Specifically, the strategy based on making attributions to prejudice was negatively related to both social actualization and social acceptance, and thus explained the negative link between perceived discrimination and both social actualization and social acceptance. These findings demonstrate that making attributions to prejudice does not necessarily serve to protect wellbeing or strengthen the group identity. This coping response probably involves ruminative processes focused on deprivation, which coping research has found to be (like blaming others) maladaptive (Larsen \& Prizmic, 2008). We can also speculate that this strategy is linked to acculturative attitudes or practices of separation, which have actually been shown to provoke more depression and loneliness than the assimilation strategy (Abu-Rayya, 2007).

However, a special attention should be paid to the differential effects of making attributions 
to prejudice on particular aspects of social wellbeing. First, our research provides empirical evidence that shows that attributing negative outcomes to prejudice reinforces the feeling of being a useful member of a society or community. That is, immigrants who react against discrimination by denouncing its negative consequences for their ingroup feel that they are contributing to the society, probably by increasing awareness of injustices immigrants experience pervasively. In turn, attributions to prejudice explained the negative relationship between two aspects of social wellbeing that refer to trust in others and the belief in their kindness (i.e., social acceptance) on the one hand, and being hopeful about the future of the society or believing in its potential and growth, (i.e., social actualization) on the other. Such opposite pattern of results for social contribution and social acceptance, and actualization is particularly significant because it demonstrates that attributing negative outcomes to prejudice may have multiple faces. Our study shows that, among immigrants claiming, discrimination does strengthen the perception of one's social value but simultaneously is related to lower social trust and a more critical and less optimistic view of the host society.

Yet, we did not find mediating effects of making attributions to prejudice on social integration and social coherence. This could be caused by some limitations of our research (see the following paragraphs of the discussion) such as low reliability of attributions to prejudice measure and thus future research should address this issue in testing effects of this strategy on different aspects of wellbeing. On the other hand, perhaps the lack of significant effects on this two specific dimensions of social wellbeing is because, the effects of making attributions to prejudice on these dimensions could be ambivalent and we would need to take into account the effects of other variables (such as the internal versus external focus of making such attributions). For instance, it could be that for some participants making attributions to prejudice would decrease the perception of social coherence because of the difficulty of understanding why discrimination persists, whereas others would make sense of their social world by making attributions to discrimination (and thus perceiving more social coherence by assuming that the world is unjust). As for social integration, we can speculate that this result may depend of how participants define their community and social universe. If immigrants define their community as mostly composed of their co-ethnic peers, then making attributions to prejudice may be associated with a stronger feeling of being part of this community. The opposite effect would be expected, however, if immigrants define their community as a host society. Then, making attributions to prejudice may be costly for social integration.

Further research should clarify inconsistencies in the literature that still remain unaddressed. Integrating in a more nuanced way the social identity framework could enhance understanding the consequences attributions to prejudice have for the wellbeing of minority groups. For instance, a belief that the social situation is changeable also increases wellbeing, because immigrants believe they can contribute to the improvement of the rights and treatment of immigrants as a group and mobilize collectively (Bobowik et al., 2017; Mummendey et al., 1999; Tajfel \& Turner, 1979). Therefore, when minority group members believe racism and discrimination can be battled, attributions to prejudice may have beneficial effects on wellbeing. However, where minorities feel helpless about their civil rights, attributions to prejudice may have an opposite effect for psychological functioning of an individual. In the same line, Crocker and Major (1994) argue that when prejudice is perceived as illegitimate, attributions to prejudice can be considered external because the prejudiced society, not the target, is blamed for the discrimination. In contrast, when prejudice is perceived as just, attributions to prejudice might be internal because the target of prejudice blames the self for the negative outcome. Stroebe et al. (2011) found that a belief in a just world attenuated the negative effects of perceived pervasive discrimination, though they did not confirm Major and O'Brien's (2005) findings whereby system-justifying beliefs were negatively related to wellbeing under conditions 
of strong ethnic identity. In the same vein, future research could examine the role that other dimensions of attributional styles may play in the positive or negative effects of making attributions to prejudice. Pervasiveness or variability over time of the cause (Weiner, 1972) could be another factor to be taken into account. We already know that only when discrimination is perceived as pervasive (versus rare), attributions to prejudice are harmful (Stroebe et al., 2011). However, these effects should be replicated and thus able to generalize over other type of social groups, such as foreignborn immigrants. Future studies could also look at the differences that could emerge in effects on wellbeing between making attributions to global (my ethic background) versus specific (wearing veil) aspects of discrimination. Interactions between different dimensions of attribution styles referred to group-based discrimination also could be explored. Group identification, positively related to attributions to prejudice (Eccleston \& Major, 2006; Major et al., 2003), could be also taken into account as an additional factor determining the way attributions to prejudice enhance or weaken minority group members wellbeing. Finally, another avenue of research is to compare the way attributions to prejudice work for different types of minority groups or more specifically immigrants simultaneously.

This study involves limitations that should be taken into account in future research. The first important limitation concerns the crosssectional nature of this research and thus we cannot draw conclusions about the predictive validity of making attributions to prejudice with regard to immigrants' wellbeing. Experimental and/or longitudinal research should address this issue in future in order to confirm the actual impact of making attributions to prejudice and discrimination on psychological functioning in both laboratory-created and real-life low-status groups. There is a need for future sound methodological research considering wellbeing as a construct both multi-dimensional and hierarchical in nature. Moreover, there is a need to include implicit measures in studies with stigmatized populations, since it was shown that there is a lack of association between implicit and explicit measures of self-concept. Finally, objective measures of wellbeing also need to be developed in future research. In addition, in order to measure the identity management strategy more accurately, there is still a need for further and more in-depth research, including cross-cultural validation studies. Future research should also improve the measurement of making attributions to prejudice, a measure that showed low internal consistently and should be improved in future studies. However, such a low reliability with a measure including only three items and in a population of foreign-born immigrants may not be as surprising. Another important limitation of the present research concerns the crosscultural generalizability of our findings. The data presented here were all collected in the Basque Country. Future research should extend the findings to other cultural contexts, as well as other cultural groups of immigrants.

The strength of the current research is its large quasi-random sample obtained through a probability sampling procedure by ethnicity, with stratification by age and sex, representative of the major immigrant groups in the Spanish context. This sample is strongly representative of the main ethnic groups within the immigrant population in Spain, including both documented and undocumented individuals. Furthermore, this study combines the social psychology perspective on identity management with positive psychology, through the inclusion of societal aspects of wellbeing for measuring immigrants' adaptation in the host society. The findings of this study may have important practical implications at designing interventions with immigrant population. Further studies should explore more extensively the significance of attributions to prejudice for both the personaland group-level adaptation of immigrants.

\section{Acknowledgements}

This research was supported by the University of the Basque Country [grant number: 9/UPV00109.231-13645/2001/2007]; 
and the Spanish Ministry of Economy and Competitiveness (MINECO) [grant number: SI2014-51923-P].

\section{References}

Abramson, L.Y., Seligman, M.E.P., \& Teasdale, J. (1978). Learned helplessness in humans. Critique and reformulation. Journal of Abnormal Psychology, 87, 49-74

Abu-Rayya, H. M. (2007). Acculturation and its determinants among adult immigrants in France. International Journal of Psychology, 43(1), 1-9. http://doi.org/10.1080/0020759 0701700537

Abu-Rayya, H. M., \& Abu-Rayya, M. H. (2009). Acculturation, religious identity, and psychological well-being among Palestinians in Israel. International Journal of Intercultural Relations, 33(4), 325-331. http ://doi.org/10.1016/j.ijintrel.2009.05.006

Aierdi, X., Basabe, N., Blanco, C., \& Oleaga, J.A. (2008). Población Latinoamericana en la CAPV 2007 [Latino population in The Basque Country]. Bilbao: Ikuspegi and UPV/ EHU. http://www.ikuspegi-inmigracion.net /documentos/documentos internos/pob la t_2007_web.pdf

Basabe, N. \& Bobowik, M. (2013). Estatus grupal, discriminación, y adaptación en inmigrantes latinoamericanos y africanos en España [Group status, discrimination and adjustment in Latino and African immigrants in Spain]. Psicoperspectivas, 12(1), 5-29. http://doi.org/10.5027/psicope rspectivas-vol12-issue1-fulltext-237

Basabe, N., Páez, D., Aierdi, X., \& JiménezAristizabal, A. (2009). Calidad de vida, bienestar subjetivo y salud: Inmigrantes en la CAPV. Zumaia: Ikuspegi - Observatorio Vasco de Inmigración. Recuperado de http://www.ikuspegi.org/documentos/in vestigacion/es/3ikusgai_salud_inmigracion ikuspegi.pdf ISBN: 978-84-9860-215-9

Basque Observatory of Immigration (2017). Panorámica 65 - Población de origen extranjero en la CAE 2017 [Panorámica 65 - Population of foreign origin in the CAE 2017]. Retrieved from http://www.ikuspegi.eus/documentos/ panoramicas/es/panoramica65casOK.pdf

Blanz, M., Mummendey, A., Mielke, R., \& Klink, A. (1998). Responding to negative social identity: A taxonomy of identity management strategies. European Journal of Social Psychology, 28(5), 697-729. http://doi .org/10.1002/(SICI) 1099-0992

Bobowik, M., Basabe, N., \& Páez, D. (2014). "Heroes of adjustment": Immigrant's Stigma and Identity Management. International Journal of Intercultural Relations, 41, 112-124. http://doi.org/10.1016/j.ijintrel.2 014.04 .002

Bobowik, M., Basabe, N., \& Páez, D. (2015). The Bright Side of Migration: Hedonic, Psychological, and Social Wellbeing in Immigrants in Spain. Social Science Research, 51, 189-204. http://doi.org/10.10 16/j.ssresearch.2014.09.011

Bobowik, M., Basabe, N., Páez, D., \& Rosel, J. (2017). Status hierarchies among immigrants in Spain: Responding to migrant status through individualistic and collectivistic strategies and wellbeing (Manuscript submitted for publication).

Bobowik, M., Martinovic, B. Basabe, N., Barsties, L., \& Wachter, G. (2017). "Healthy" Identities? Revisiting Rejection-Identification and RejectionDisidentification Models among Voluntary and Forced Immigrants. European Journal of Social Psychology, special issue "Social Identities as Social Cures". Accepted manuscript online. http://doi.org/10.1002/e jsp.2306

Branscombe, N. R., Schmitt, M. T., \& Harvey, R. D. (1999). Perceiving pervasive discrimination among African Americans: Implications for group identification and well-being. Journal of Personality and Social Psychology, 77(1), 135-149. http://doi.org/1 0.1037/0003-066X.44.4.709

Cheng, H., \& Furnham, A. (2003). Attributional style and self-esteem as predictors of 
psychological well being. Counselling Psychology Quarterly, 16(2), 121-130. http:/ /doi.org/10.1080/09515070302752

Crocker, J., \& Major, B. (1989). Social stigma and self-esteem: The self-protective properties of stigma. Psychological Review, 96, 608-630.

Crocker, J., \& Major, B. (1994). Reactions to stigma: The moderating role of justifications. In M. P. Zanna, \& J. M. Olson (Eds.), Ontario symposium on personality and social psychology, Vol. 7. The psychology of prejudice (pp. 289-314). Hillsdale, NJ: Lawrence Erlbaum Associates.

Crocker, J., Major, B. \& Steele, C. (1998). Social Stigma. In D. Gilbert, S. T. Fiske, \& G. Lindzey (Eds.), The Handbook of Social Psychology (4th ed., Vol. 2, pp. 504-553). New York: McGraw Hill. http://doi.org/10. 1002/9780470561119

Crocker, J., Voelkl, K., Testa, M., \& Major, B. (1991). Social stigma: The affective consequences of attributional ambiguity. Journal of Personality and Social Psychology, 60 (2), 218-228. http://doi.org/10.1037/002 2-3514.60.2.218

Eccleston, C. P., \& Major, B. N. (2006). Attributions to Discrimination and SelfEsteem: The Role of Group Identification and Appraisals. Group Processes $\mathcal{E}$ Intergroup Relations, 9(2), 147-162. http://d oi.org/10.1177/1368430206062074

Efron, B., \& Tibshirani, R. J. (1993). An introduction to the bootstrap. Boca Raton, FL: Chapman \& Hall.

European Union Agency for Fundamental Rights. (2010). European Union Minorities and Discrimination Survey (EU-MIDIS) (Data in focus report 5: multiple discrimination). http://doi.org/10.2811/951 59.

Eurostat (2012). Europe in Figures. Eurostat yearbook 2012. Luxembourg: Publications Office of the European Union. http://doi.o $\mathrm{rg} / 10.2785 / 20539$

Finch, B. K., Kolody, B., \& Vega, W. A. (2000). Perceived Discrimination and Depression among Mexican-Origin Adults in California. Journal of Health and Social
Behavior, 41(3), 295-313. http://doi.org/10. 2307/2676322

González-Castro, J. L., \& Ubillos, S. (2011). Determinants of psychological distress among migrants from Ecuador and Romania in a Spanish city. International Journal of Social Psychiatry, 57(1), 30-44. ht tp://doi.org/10.1177/0020764009347336

Guimond, S., \& Tougas, F. (1996). Sentimientos de injusticia y acciones colectivas: La privación relativa [Feelings of injustice and collective action: Relative deprivation]. In R. Y. Bourhis \& J. P. Leyens (Eds.), Estereotipos, discriminación y relaciones intergrupales (pp. 171-193). Madrid: McGrawHill.

Heider, F. (1958). The Psychology of Interpersonal Relations. New York: Wiley.

Hu, L., \& Bentler, P. M. (1999). Cutoff criteria for fit indexes in covariance structure analysis: Conventional criteria versus new alternatives. Structural Equation Modeling, 6(1), 1-55. http://doi.org/10.1080/1070551 9909540118

International Organization for Migration. (2010). Migration and the economic crisis in the European Union: implications for policy. Brussels: International Organization for Migration. Retrieved from http://publications.iom.int/bookstore/ free/Migration_and_the_Economic_Crisis. pdf

Iwamoto, D. K., \& Liu, W. M. (2010). The impact of racial identity, ethnic identity, Asian values and race-related stress on Asian Americans' well being. Journal of Counseling Psychology, 57(1), 79-91. http://doi.org/10.1 037/a0017393

Joshanloo, M., Bobowik, M., \& Basabe, N. (2016). Factor structure of mental well-being: Contributions of exploratory structural equation modeling. Personality and Individual Differences, 102, 107-110.

Kaiser, C. R., \& Miller, C. T. (2001). Stop complaining! The social costs of making attributions to discrimination. Personality and Social Psychology Bulletin, 27(2), 254-263. 
Kaiser, C. R., Dyrenforth, P. S., \& Hagiwara, N. (2006). Why are attributions to discrimination interpersonally costly? A test of system- and groupjustifying motivations. Personality and Social Psychology Bulletin, 32(11), 1523-1536. htt p://doi.org/10.1177/0146167206291475

Kelley, H. H. (1967). Attribution theory in social psychology. In D. Levine (Ed.), Nebraska Symposium on Motivation, 15, (pp. 129-238). Lincoln: University of Nebraska Press

Keyes, C. (1998). Social well-being. Social Psychology Quarterly, 61 (2), 121-140. http:/ /doi.org/10.2307/2787065

Keyes, C. (2006). Subjective well-being in mental health and human development research worldwide: An introduction. Social Indicators Research, 77(1), 1-10. http: //doi.org/10.1007/s11205-005-5550-3

Keyes, C. (2009). The Black-White Paradox in Health: Flourishing in the Face of Social Inequality and Discrimination. Journal of Personality, 77(6), 1677-1706. http://doi.org /10.1111/j.1467-6494.2009.00597.x

Larsen, R. J., \& Prizmic, Z. (2008). Regulation of emotional well-being: Overcoming the hedonic treadmill. In M. Eid \& R.J. Larsen (Eds.), The science of subjective well-being (pp. 258-289). New York: Guilford.

Major, B., \& O'Brien, L. T. (2005). The social psychology of stigma. Annual Review of Psychology, 56(1), 393-421. http://doi.org/1 0.1146/annurev.psych.56.091103.070137

Major, B., Quinton, W. J., \& Schmader, T. (2003). Attributions to discrimination and self-esteem: Impact of group identification and situational ambiguity. Journal of Experimental Social Psychology, 39(3), 220-213. http://doi.org/10.1016/S0022-103 1(02)00547-4

Mesch, G. S., Turjeman, H., \& Fishman, G. (2008). Perceived discrimination and the well-being of immigrant adolescents. Journal of Youth and Adolescence, 37(5), 592-604.

Meuleman, B., Davidov, E., \& Billiet, J. (2009). Changing attitudes toward immigration in Europe, 2002-2007: A dynamic group conflict theory approach. Social Science Research, 38(2), 352-365. http://doi.org/10. 1016/j.ssresearch.2008.09.006

Miller, C. T., \& Kaiser, C. R. (2001). A theoretical perspective on coping with stigma. Journal of Social Issues, 57(1), 73-92. http://doi.org/ 10.1111/0022-4537.00202

Mummendey, A., Kessler, T., Klink, A., \& Mielke, R. (1999). Strategies to cope with negative social identity: Predictions by social identity theory and relative deprivation theory. Journal of Personality and Social Psychology, 76(2), 229-245. http://doi.org/10.1037//00 22-3514.76.2.229

Muthén, L. K., \& Muthén, B. O. (2010). Mplus (version 6). Los Angeles, CA: Muthén \& Muthén.

Pascoe, E., \& Smart-Richman, L. (2009). Perceived Discrimination and Health: A Meta-Analytic Review. Psychological Bulletin, 135(4), 531-554. http://doi.org/10. 1037/a0016059

Ryan, R. M., \& Deci, E. L. (2001). On happiness and human potentials: A review of research on hedonic and eudaimonic well-being. Annual Review of Psychology, 52 (1), 141-166. http://doi.org/0066-4308/0 1/0201-0141

Ryff, C. D., Keyes, C. L. M., \& Hughes, D. L. (2003). Status inequalities, perceived discrimination, and eudaimonic well-being: Do the challenges of minority life hone purpose and growth? Journal of Health $\mathcal{E}$ Social Behavior, 44(3), 275-291. http://doi.o $\mathrm{rg} / 10.2307 / 1519779$

Schmitt, M. T., Branscombe, N. R., Postmes, T., $\&$ Garcia, A. (2014). The Consequences of Perceived Discrimination for Psychological Well-Being: A Meta-Analytic Review. Psychological Bulletin, 140, 921-948. http://d oi.org/10.1037/a0035754

Schmitt, M.T., \& Branscombe, N.R. (2002). The meaning and consequences of perceived discrimination in disadvantaged and privileged social groups. In W. Stroebe \& M. Hewstone (Eds.), European review of social psychology (Vol. 12, pp. 167-199). Chichester: Wiley. 
Seligman, M.E.P., Abramson, L.Y., Semmel, A. \& Von Baeyer, C. (1979). Depressive attributional style. Journal of Abnormal Psychology, 88, 242-247.

Sevillano, V., Basabe, N., Bobowik, M. \& Aierdi, X. (2014). Health-related quality of life and perceived discrimination among immigrants and natives in Spain. Ethnicity E Health, 19(2), 178-197. http://doi.org/10 $.1080 / 13557858.2013 .797569$

Skinner, E. A., Edge, K., Altman, J., \& Sherwood, H. (2003). Searching for the structure of coping: A review and critique of category systems for classifying ways of coping. Psychological Bulletin, 129(2), 216-269. http:// doi.org/10.1037/0033-2909.129.2.216

Stroebe, K., Dovidio, J., Barreto, M., Ellemers, N., \& John, M. S. (2011). Is the world a just place? Countering the negative consequences of pervasive discrimination by affirming the world as just. British Journal of Social Psychology, 50(3), 484-500. http:// doi.org/10.1348/014466610X523057

Swim, J. K. \& Stangor, C. (1998). Prejudice: The target's perspective. New York: Academic Press.

Tajfel, H., \& Turner, J. (1979). An integrative theory of intergroup conflict. In W. G. Austin \& S. Worchel (Eds.), The social psychology of intergroup relations (pp. 33-47). Monterey, CA: Brooks/Cole.

Tucker, L., \& Lewis, C. (1973). A reliability coefficient for maximum likelihood factor analysis. Psychometrika, 38(1), 1-10. http:// doi.org/10.1007/BF02291170

Weiner, B. (1972). Attribution theory, achievement motivation, and the educational process. Review of educational research, 42 (2), 203-215. http://doi.org/10. 3102/00346543042002203

Williams, D. R., \& Mohammed, S. A. (2009). Discrimination and racial disparities in health: Evidence and needed research. Journal of Behavioral Medicine, 32 (1), 20-47. http://doi.org/10.1007/s10865-008-9185-0

Williams, D. R., Neighbors, H. W., \& Jackson, J. S. (2003). Racial/Ethnic Discrimination and Health: Findings from Community Studies. American Journal of Public Health, 93(2), 200-208. http://doi.org/10.2105/AJP H.93.2.200

Zautra, A.J., Guenther, R.T. \& Chartier, G.M. (1985). Attributions for real and hypothetical events: Their relation to selfesteem and depression. Journal of Abnormal Psychology, 94, 530-540.

Zlobina, A., Basabe, N., Páez, D., \& Furnham, A. (2006). Sociocultural adjustment of the immigrants. International Journal of Intercultural Relations, 30(2), 195 - 211. htt p://doi.org/10.1016/j.ijintrel.2005.07.005

\section{Notes}

* Research article 